\title{
Effects of environmental taxation on district heat production structures
}

\author{
Leif Gustavsson $^{1,2}$, Nguyen Le Truong ${ }^{2}$, Ambrose Dodoo ${ }^{2, *}$, Roger Sathre ${ }^{2}$ \\ ${ }^{1}$ Linnaeus University, 35195 Växjö, Sweden \\ ${ }^{2}$ Mid Sweden University, 83125 Östersund, Sweden \\ *Corresponding author.Tel: +46 63165383,Fax:+46 63165500,E-mail: ambrose.dodoo@miun.se
}

\begin{abstract}
In this study, we explore how different environmental taxation regimes influence the design of costoptimal district heat production systems and the primary energy use for district heat production. Our calculations are based on the heat load duration curve of a district heat production system in Östersund, Sweden. Using the system's measured daily district heat load curve from $1^{\text {st }}$ May 2008 to $30^{\text {th }}$ April 2009, we model four costoptimal district heat production systems based on four environmental taxation scenarios. The design of the district heat production under the different taxation scenarios is based on expected utilization time and on the production units which give the lowest heat production cost. We find that primary energy use varies strongly when different technologies and fuels are used under the different environmental taxation scenarios. However environmental taxation has a minimal effect on district heat production cost for optimally designed district heat production systems. Fossil fuels become less competitive as the environmental taxation increases. However, light fuel oil boiler for the peak load production remains viable due to low utilization time and investment cost.
\end{abstract}

Keywords: District heat production, CHP, Boilers, Fossil fuel, Biofuel, Environmental tax, Primary energy, Cost

\section{Introduction}

Energy security and the impact of energy systems on the global climate are important energy policy concerns in the European Union, including in Sweden. Several strategies can be used to address these concerns, including promotion of more efficient energy production technologies, and conversion to renewable and low carbon fuels. District heating based on combined heat and power (CHP) production is primary energy efficient [1], and can use biomass-based fuels.

In Sweden, district heating with CHP is increasingly common, and is the main source of heat for multi-story residential and non-residential buildings [2]. In 2008, district heating accounted for $50 \%$ (about 50TWh) of the total space and tap water heating [3]. The energy input for the Swedish district heat production is dominated by biomass, which accounted for $48 \%$ of total input in 2008 [4]. The Swedish government energy policy aims at further increasing the share of biomass. Policy instruments to realize this include environmental taxes on fuels, tradable green electricity certificates (GEC) and obligated quota mechanism of GEC for customers [2].

The utilization time of district-heat production units varies and is very small for the units that cover peak-load demand. Therefore, the investment costs of these units are much more important than the operation costs. Low investment fossil fuel-based technologies are often used even though they are associated with higher external cost. Environmental taxation can be an important policy instrument to restructure district heating systems into more sustainable form. Such policy instrument may influence the choice of technologies and fuels for district heat production units.

In this study we explore how different environmental taxation regimes influence district heat production structures. We investigate the choice of production units and fuels for cost-optimal district heat production for the different environmental taxation scenarios, and calculate the primary energy use and the cost of district heat production. 


\section{Method and assumptions}

Our analysis is based on the measured daily district heat load curve of a district heat production system in Östersund, Sweden from $1^{\text {st }}$ May 2008 to $30^{\text {th }}$ April 2009. Figure 1 shows the measured heat load of the production system during this period, arranged in descending order. During this 12 month period, the output of the production system was 210 GWh electricity and 612 GWh heat. Based on the district heat load curve, we model four costoptimal district heat production systems based on four environmental taxation scenarios. Figure 2 presents a schematic diagram of the study.

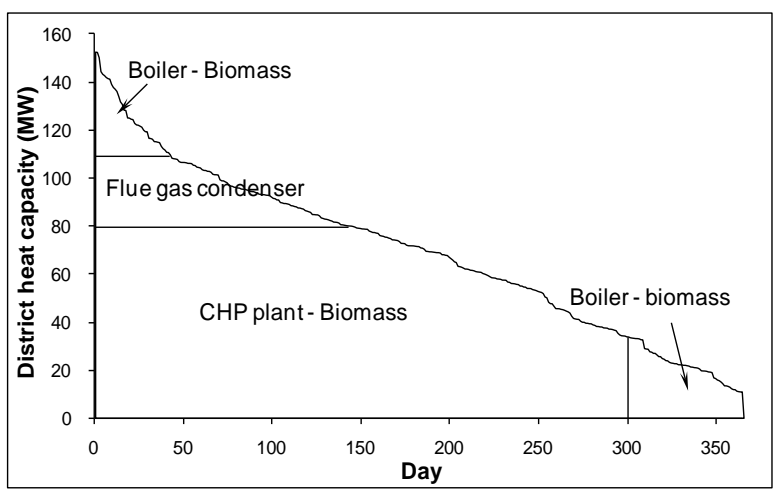

Fig. 1. Reference heat load duration curve

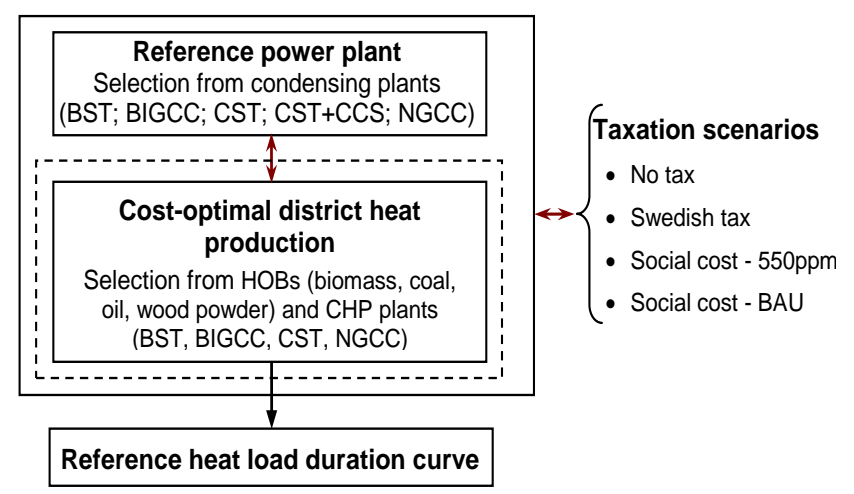

Fig. 2. Schematic diagram of the analysis

We use four environmental taxations scenarios to explore their effect on the structure of district heat production. The taxations scenarios are: (i) the No tax scenario with the year 2008 Swedish price of fuels with zero taxes; (ii) the Swedish tax scenario with the year 2008 Swedish prices and taxes on fuels, comprising of a carbon tax of $€ 386 / \mathrm{t} \mathrm{CO}_{2}$ for emissions related to non-electricity production, an energy tax that varies for different fossil fuels used for non-electricity production, and an average green electricity certificate (GEC) benefit of $€ 12.5 / \mathrm{MWh}_{\mathrm{e}}$ of produced green electricity [5]; (iii) the Social cost-550 ppm scenario with the year 2008 fossil fuel prices excluding taxes, plus a carbon damage cost of $€ 20.55 / \mathrm{t} \mathrm{CO}_{2}(\$ 30 / \mathrm{t}$ $\mathrm{CO}_{2}$ ) corresponding to the $550 \mathrm{ppm}$ emission scenario by Stern [6]; (iv) the Social cost-BAU scenario with the year 2008 fossil fuel prices excluding taxes, plus a carbon damage cost of $€ 58.23 / \mathrm{CO}_{2}$ (\$85/t CO $\mathrm{CO}_{2}$ ) corresponding to the business as usual (BAU) emission scenario by Stern (2006). The costs of the fuels under the various scenarios are shown in Table 1.

Table 1. Fuel costs under the various scenarios $\left(\epsilon_{2008} / M W h\right)$

\begin{tabular}{lcccc}
\hline & \multicolumn{4}{c}{ Scenarios } \\
\cline { 2 - 5 } Fuel type & No tax & Swedish tax & Social cost-550 ppm & Social cost - BAU \\
\hline Fuel oil & 29.7 & 62.9 & 36.1 & 47.7 \\
Coal & 8.0 & $46.3(17.4)^{\mathrm{a}}$ & 15.5 & 29.3 \\
Forest fuel & 16.3 & 16.3 & 16.5 & 16.8 \\
Natural gas & 33.7 & $37.6(37.9)^{\mathrm{a}}$ & 37.9 & 45.6 \\
Wood powder $^{\mathrm{b}}$ & 26.1 & 26.1 & 26.4 & 26.9 \\
\hline
\end{tabular}

${ }^{\mathrm{a}}$ CHP plant.

${ }^{\mathrm{b}}$ Estimated based on forest fuel cost.

We select the district heat production units for each taxation scenario based on the utilization time and lowest district heat cost. We consider the fuels and technologies shown in Table 2. The technologies consist of CHP plants and heat only boilers (HOB). The CHP plants are 
based on biomass steam turbine (BST); biomass integrated gasification combined-cycle (BIGCC); coal steam turbine (CST); and natural gas combined-cycle (NGCC) technologies.

Table 2. Investment cost, fixed and variable costs and conversion efficiency of different technologies. The data is based on lower heating values (LHV).

\begin{tabular}{|c|c|c|c|c|c|c|}
\hline \multirow[t]{2}{*}{ Technology } & \multirow[t]{2}{*}{ Capacity } & \multirow{2}{*}{$\begin{array}{c}\text { Investmen } \\
\text { t cost }\end{array}$} & \multirow{2}{*}{$\begin{array}{c}\text { Fixed } \\
\text { O\&M cost } \\
\end{array}$} & \multirow{2}{*}{$\begin{array}{c}\text { Variable } \\
\text { O\&M cost }\end{array}$} & \multicolumn{2}{|c|}{ Efficiency (\%) } \\
\hline & & & & & Heat & Elect. \\
\hline Heat-only boiler (HOB): & $\left(M W_{\text {heat }}\right)$ & $\left(€ / k W_{\text {heat }}\right)$ & $\left(€ / k W_{\text {heat }}\right)$ & $\left(€ / M W h_{\text {fuel }}\right.$ & & \\
\hline Biomass $^{\mathrm{a}}$ & & 646 & 12.92 & 1.95 & 110 & - \\
\hline Wood powder ${ }^{b}$ & & 430 & 8.6 & 1.95 & 95 & - \\
\hline $\mathrm{Oil}^{\mathrm{a}}$ & & 300 & 4.5 & 0.65 & 90 & - \\
\hline Coal $^{\mathrm{C}}$ & & 690 & 17.3 & 2.59 & 90 & - \\
\hline CHP plants: & $\left(M W_{\text {heat }}\right)$ & $\left(€ / k W_{\text {heat }}\right)$ & $\left(€ / k W_{\text {heat }}\right)$ & $\left(€ / M W h_{f u e l}\right.$ & & \\
\hline $\mathrm{BST}^{\mathrm{c}}$ & 80 & 1150 & 17.3 & 2.6 & 80 & 30 \\
\hline $\mathrm{BIGCC}^{\mathrm{a}}$ & 80 & 1700 & 42.5 & 3.1 & 47 & 43 \\
\hline $\mathrm{NGCC}^{\mathrm{a}}$ & 80 & 950 & 23.8 & 1.0 & 43 & 46 \\
\hline $\mathrm{CST}^{\mathrm{c}}$ & 80 & 1350 & 33.8 & 3.1 & 59 & 30 \\
\hline Condensing power plant: & $\left(M W_{\text {elec }}\right)$ & $\left(€ / k W_{\text {elec }}\right)$ & $\left(€ / k W_{\text {elec }}\right)$ & $\left(\begin{array}{c}€ / M W h_{f u e l} \\
)\end{array}\right.$ & & \\
\hline $\mathrm{CST}^{\mathrm{c}}$ & 400 & 1200 & 24.9 & 3.12 & - & 47 \\
\hline CST with CCS $^{\mathrm{C}}$ & 400 & 1900 & 74.8 & 5.2 & - & 37 \\
\hline $\mathrm{NGCC}^{\mathrm{c}}$ & 400 & 620 & 18.7 & 1.04 & - & 58 \\
\hline $\mathrm{BST}^{\mathrm{d}}$ & 400 & 1200 & 20 & 2.39 & - & 45 \\
\hline $\mathrm{BIGCC}^{\mathrm{a}}$ & 100 & 1680 & 42 & 3.12 & - & 47 \\
\hline $\begin{array}{l}\text { Encompasses forest fu } \\
\text { investment cost between [8 } \\
\text { b Swedish Wood Fuel Ass } \\
{ }^{c} \text { Hansson et al. [8] } \\
\text { d Estimated from CEC [7] }\end{array}$ & $\begin{array}{l}\text { s; estim } \\
\text { and [7] } \\
\text { iation ar }\end{array}$ & $\begin{array}{l}\text { from } \\
\text { vedish }\end{array}$ & with ad & tment fol & le & $\begin{array}{l}\text { ence } \\
\text { nent }\end{array}$ \\
\hline
\end{tabular}

The calculation of the heat production cost is based on the following equation from Gustavsson [10]:

$$
C_{\text {heat }}=\frac{C_{\text {vom }}}{\eta_{\text {heat }}}+\frac{C_{\text {fuel }}}{\eta_{\text {heat }}}-V_{\text {elec }} \times \alpha+\frac{C R F \times C_{c a p}+C_{\text {fom }}}{t}
$$

where $C_{\text {heat }}$ is the heat production cost ( $\left.€ / \mathrm{MW}_{\text {heat }}\right), C_{\text {vom }}$ is the variable operation and maintenance $(\mathrm{O} \& \mathrm{M})$ costs of the plant $\left(€ / \mathrm{MWh}_{\text {fuel }}\right)$, $\eta_{\text {heat }}$ is the efficiency of heat production of the plant, $C_{\text {fuel }}$ is the fuel cost of the plant $\left(€ / \mathrm{MWh}_{\text {fuel }}\right), V_{\text {elec }}$ is the value of produced electricity ( $€ / \mathrm{MWh}_{\text {elec }}$ ), $\alpha$ is the electricity-to-heat ratio of the plant, $C R F$ is the capital recovery factor of the plant, $C_{\text {cap }}$ is the capital cost of the plant ( $€ / \mathrm{MW}_{\text {heat }}$ ), $C_{\text {fom }}$ is the annual fixed O\&M costs of the plant ( $\left.€ / \mathrm{MW}_{\text {heat }}\right)$, and $t$ is the utilization time of the plant.

For district heating systems with CHP production, the production cost of heat may be determined by subtracting the value of the cogenerated electricity from the total production cost of the CHP plant [11]. We calculate the value of cogenerated electricity using the subtraction method, where we consider the cogenerated electricity as by-product and assume 
its value to be equivalent to the cost of electricity produced with a reference condensing power plant [12]. We calculate the cost of the cogenerated electricity as the lowest production cost from the condensing power plants (Table 2) for each taxation scenario. We assume the same technologies as for cogeneration but also add carbon capture and storage (CCS) for the CST technology. Data for condensing power production from CST with CCS is from Hansson et al. [8]

We calculate the primary energy use and the heat and electricity generated by the cost-optimal district heat production systems based on the operation schedules, production units and fuels. We consider fuel cycle energy inputs in our calculations.

For all the production units, we assume a discount rate of 6\%, an economic plant life of 25 years and a maximum operating period of 7200 hours per year. We use exchange rates of $\mathrm{EUR} / \mathrm{SEK}=9.62$ and USD/SEK= 6.59, based on the average rates for 2008.

\section{Results and discussion}

The calculated cost of electricity from the condensing power plants under the various taxation scenarios is shown in Table 3. The numbers in bold show the lowest production cost for each taxation scenario, and hence become the reference condensing power plant for each scenario. CST emerges as the reference condensing power plant for electricity production in all scenarios except for the Social cost-BAU scenario. For the Social cost-BAU scenario, BST emerges as the reference condensing power plant. However, the cost difference between BST and CST is small for the Swedish tax and Social cost-550 ppm scenarios.

Table 3. The cost of electricity production for the various taxation scenarios ( $€ / M W h)$.

\begin{tabular}{lcccc}
\hline Technology & No tax & Swedish tax & Social cost-550 ppm & Social cost-BAU \\
\hline CST & $\mathbf{4 0 . 2}$ & $\mathbf{4 4 . 6}$ & $\mathbf{5 6 . 1}$ & 85.4 \\
CST, CCS & 66.7 & 66.7 & 68.9 & 72.9 \\
NGCC & 69.2 & 76.5 & 76.4 & 89.7 \\
BST & 57.4 & 44.9 & 57.8 & $\mathbf{5 8 . 6}$ \\
BIG/CC & 65.4 & 52.9 & 65.8 & 66.5 \\
\hline
\end{tabular}

Figure 3(a-d) shows the cost of district heat production units as a function of the utilization time under the different taxation scenarios. The units with the lowest heat production cost are applied to the heat load profile to minimize the overall heat production cost (Figure 4a-d). For the No tax scenario a CHP-CST for base load, coal boiler for medium load and light-fuel oil boiler for peak load give the cost-optimal system (Figure 3a). Five different units give the cost-optimal system for the Swedish tax scenario (Figure 3b), including CHP-BST and CHPBIGCC for base load, wood powder boiler and biomass boiler for the medium load, and light fuel oil boiler for the peak load. However, the CHP-BIGCC may not be technically feasible as the technology is still at the demonstration stage and is not yet commercialized [13]. Therefore we select the CHP-BST plant for the base load production but show the results if CHP-BIGCC is used in a sensitivity analysis. During periods when the base load unit is shut down (after 300 days) heat demand has to be met by the medium load unit, increasing the utilization time for that unit. If this utilization time is also considered, the wood powder boiler becomes less competitive than the biomass boiler for the medium load production. Therefore a combination of CHP-BST plant for base load, biomass boiler for medium load and light fuel oil boiler for peak load gives the minimum heat production cost for the Swedish tax scenario 
(Figure 4b). Similar analyses for the Social cost-BAU and Social cost-550 ppm scenarios give the selections the production units shown in Figure 4c and d.

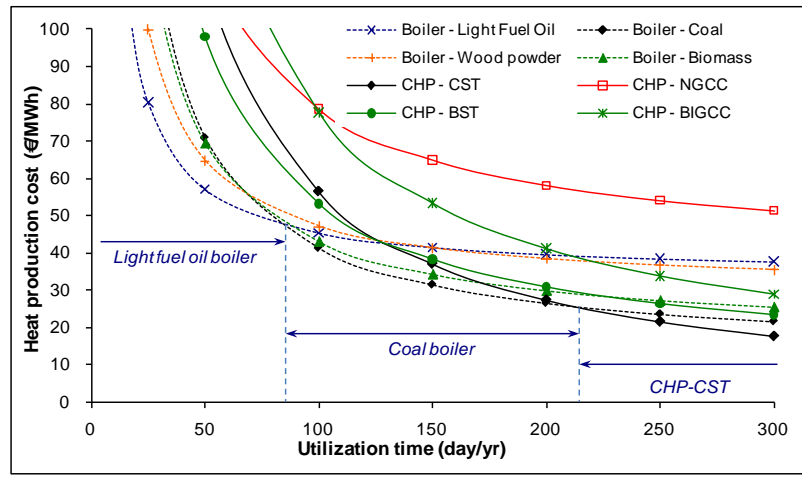

a) No tax

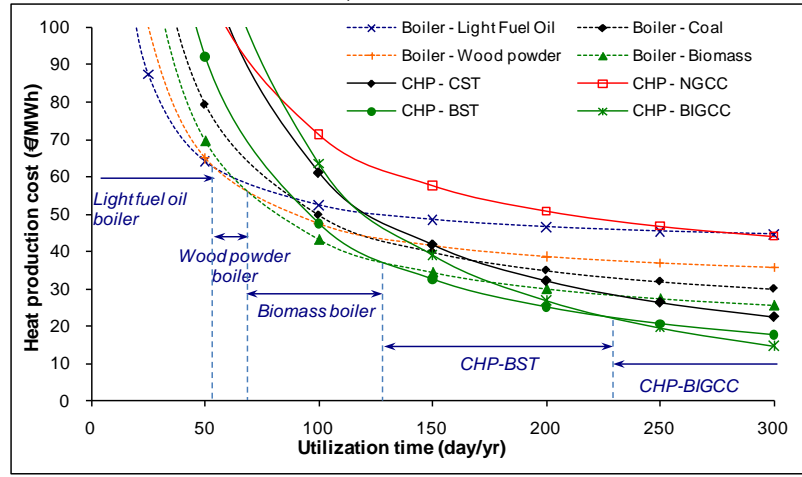

c) Social cost-550ppm

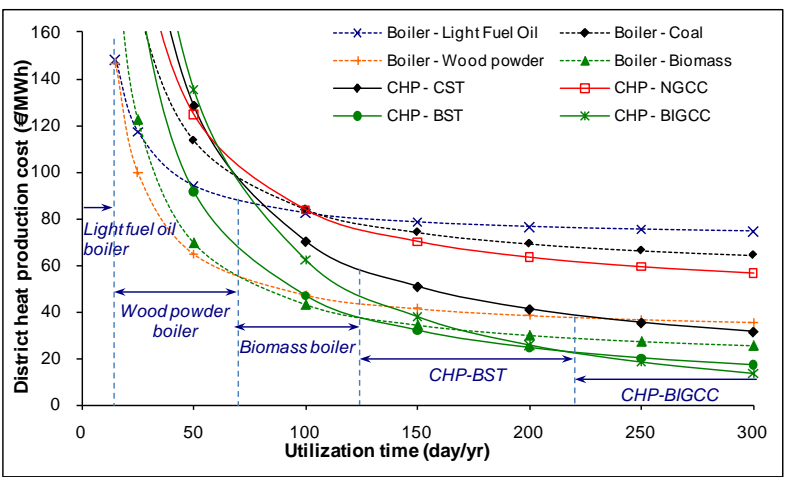

b) Swedish tax

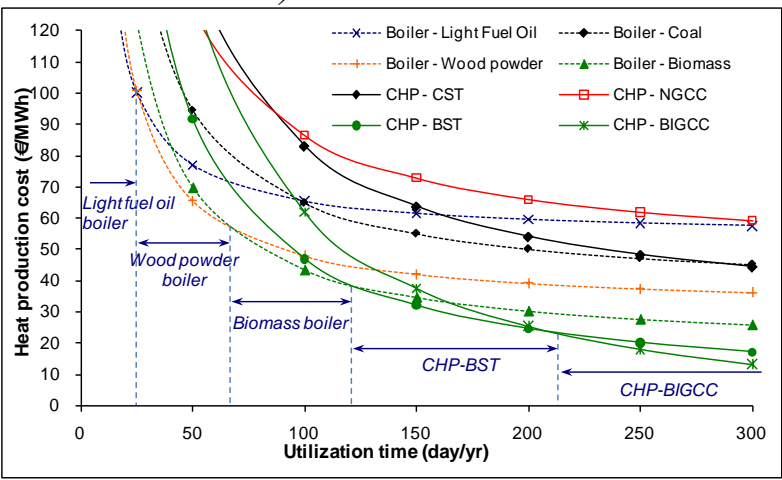

d) Social cost - BAU

Fig. 3. Performance of district heat production units under different taxation scenarios

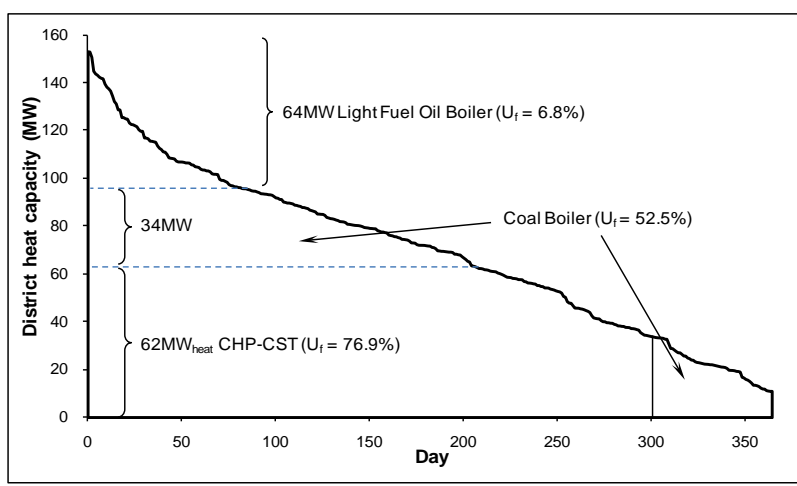

a) No tax

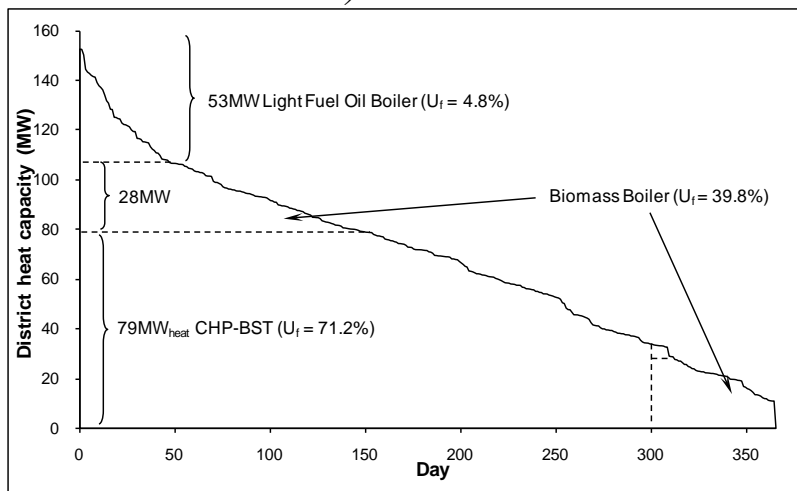

c) Social cost-550ppm

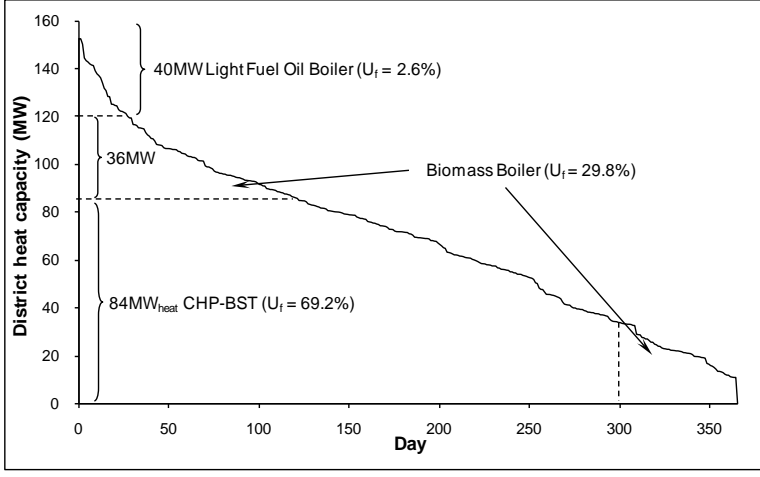

b) Swedish tax

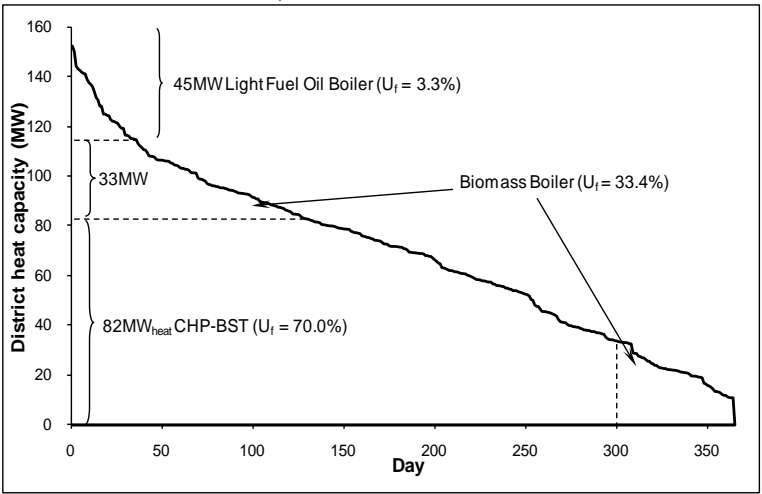

d) Social cost - BAU

Fig. 4. The cost-optimal production units satisfy heat load demand under different taxation scenarios 
Table 4 shows the production units and the capacities of the cost-optimal district heat production systems as well as the annual heat and electricity production and the annual primary energy use. District heat production is based on only fossil fuels under No tax scenario whereas in the other scenarios district heat production is based mainly on biomass, accounting for $96.4 \%$ in Social cost-550ppm scenario and $98.5 \%$ in Swedish tax scenario. Hence fossil fuels become less competitive as the environmental taxation increases. However, light fuel oil boiler for the peak load production remains viable due to low utilization time and investment cost.

Table 4. The cost-optimal district heating systems under different taxation scenarios.

\begin{tabular}{|c|c|c|c|c|}
\hline $\begin{array}{l}\text { Production unit } \\
\text { of district heat }\end{array}$ & $\begin{array}{l}\text { Capacity } \\
\left(M W_{\text {heat }}\right)\end{array}$ & $\begin{array}{c}\text { Heat generation } \\
(G W h)\end{array}$ & $\begin{array}{c}\text { Elect. generation } \\
(G W h)\end{array}$ & $\begin{array}{c}\text { Primary energy use } \\
\text { (GWh) }\end{array}$ \\
\hline \multicolumn{5}{|l|}{ No Tax: } \\
\hline CHP-CST & 62 & 418.0 & 212.0 & 793.0 \\
\hline Boiler-coal & 34 & 156.0 & & 159.0 \\
\hline Boiler-oil & 64 & 38.0 & & 47.0 \\
\hline \multicolumn{5}{|l|}{ Swedish tax: } \\
\hline CHP-BST & 84 & 509.0 & 191.0 & 658.0 \\
\hline Boiler-biomass & 36 & 94.0 & & 88.0 \\
\hline Boiler-oil & 40 & 9.0 & & 11.0 \\
\hline \multicolumn{5}{|c|}{ Social cost - 550ppm: } \\
\hline CHP- BST & 79 & 492 & 185.0 & 637.0 \\
\hline Boiler-biomass & 28 & 98 & & 92.0 \\
\hline Boiler-oil & 53 & 22 & & 27.0 \\
\hline \multicolumn{5}{|c|}{ Social cost - BAU: } \\
\hline CHP- BST & 82 & 503 & 188.0 & 650.0 \\
\hline Boiler-biomass & 33 & 96 & & 91.0 \\
\hline Boiler-oil & 45 & 13 & & 16.0 \\
\hline
\end{tabular}

Table 5 shows the district heat production cost and primary energy use for heat production under the different scenarios. The district heat productions with CHP-BST have similar district heat production cost, ranging from $€ 25.6$ to $€ 25.8$ per MWh regardless of taxation scenarios. This is slightly higher than that of the cost-optimal system under No tax scenario, which is $€ 25.0$ per MWh. The primary energy use is about $50 \%$ higher in the No tax scenario compared to the other scenarios. This is mainly because CHP is less cost-effective without any taxation, resulting in a higher use of the less efficient boilers.

Table 5. District heat production cost and primary energy use of cost-optimal systems.

\begin{tabular}{lcc}
\hline Scenario & $\begin{array}{c}\text { District heat production cost } \\
(\epsilon / \mathrm{MWh})\end{array}$ & $\begin{array}{c}\text { Primary energy for heat production } \\
(\mathrm{GWh})\end{array}$ \\
\hline No tax & 25.0 & 440.6 \\
Swedish tax & 25.8 & 325.8 \\
Social cost - 550ppm & 25.6 & 335.9 \\
Social cost - BAU & 25.6 & 311.6 \\
\hline
\end{tabular}




\section{Sensitivity analysis}

To demonstrate the potential of CHP-BIGCC technology if it is commercialized, the CHPBIGCC plant is used for the base load production for the Swedish tax, Social cost-550 ppm and Social cost-BAU scenarios as it gives the lowest district heat production cost. The optimal capacities for the production units with CHP-BIGCC are given in Table 6. The capacities of the production units and the heat generated decrease when CHP-BIGCC is used instead of CHP-BST. This is because the CHP-BIGCC system is more efficient than the CHP-BST but also more capital intensive. However, the cogenerated electricity is about twice as much for CHP- BIGCC than for the CHP-BST.

Table 6. The cost-optimal district heating systems under different taxation scenarios if CHP-BIGCC is used.

\begin{tabular}{lcccc}
\hline $\begin{array}{l}\text { Production unit } \\
\text { of district heat }\end{array}$ & $\begin{array}{c}\text { Capacity } \\
\left(M W_{\text {heat }}\right)\end{array}$ & $\begin{array}{c}\text { Heat generation } \\
(G W h)\end{array}$ & $\begin{array}{c}\text { Elect. generation } \\
(G W h)\end{array}$ & $\begin{array}{c}\text { Primary energy use } \\
(G W h)\end{array}$ \\
\hline Swedish tax: & & & & \\
CHP-BIGCC & 74 & 473 & 433.0 & 1042.0 \\
Boiler-biomass & 46 & 130 & & 122.0 \\
Boiler-oil & 40 & 9.0 & & 11.0 \\
Social cost - 550ppm: & 72 & 465.0 & 425.0 & 1024.0 \\
CHP-BIGCC & 33 & 124.0 & & 117.0 \\
Boiler-biomass & 55 & 23.0 & & 29.0 \\
Boiler-oil & & & & \\
Social cost - BAU: & & 477.0 & 437.0 & 1051.0 \\
CHP-BIGCC & 75 & 118.0 & & 20.0 \\
Boiler-biomass & 36 & 17.0 & & \\
Boiler-oil & 49 & & & \\
\hline
\end{tabular}

Table 7 shows the district heat production cost and primary energy use if CHP-BIGCC is used. The district heat production cost is $5-8 \%$ lower than when CHP-BST is used. The primary energy for district heat production is also significantly reduced compared to when CHP-BST is used. This is due to the benefits from the increased cogenerated electricity.

Table 7. District heat production cost and primary energy use of cost-optimal systems if CHP-BIGCC is used.

\begin{tabular}{lcc}
\hline Scenario & $\begin{array}{c}\text { District heat production cost } \\
(€ / M W h)\end{array}$ & $\begin{array}{c}\text { Primary energy for heat production } \\
(\text { GWh })\end{array}$ \\
\hline Swedish tax & 24.0 & 254.7 \\
Social cost $-550 \mathrm{ppm}$ & 24.3 & 288.6 \\
Social cost - BAU & 23.6 & 247.1 \\
\hline
\end{tabular}

\section{Conclusions}

In this study, we explore how different environmental taxation regimes influence the design of optimal cost district heat production system. We find that primary energy use varies strongly when different technologies are used under the different taxation scenarios. CHP is less cost-effective without any taxation, resulting in a higher use of the less efficient boilers. Fossil fuels become less competitive as the environmental taxation increases. However, light 
fuel oil boilers for the peak load production remains viable due to low utilization time and investment cost. Varying the environmental taxation has a minimal effect on the heat production cost when the biomass-based district heat production is designed for the given taxation.

CST emerges as the reference condensing power plant under all taxation scenarios except for the Social cost-BAU scenario, in which BST is the reference condensing power plant. CHPBIGCC is an emerging technology for efficient use of biomass for district heat production as this technology increases the power-to-heat ratio of CHP-based district heat production. Policy instruments that provide incentives for and eliminate barriers against this technology may be needed to implement the technology. Hence, environmental taxation can be an important policy instrument to increase the competitiveness of biomass-based CHP.

\section{References}

[1] A. Joelsson, and L. Gustavsson, District heating and energy efficiency in detached houses of differing size and construction, Applied Energy, 2 86(2), 2009, pp. 126-134.

[2] Swedish Energy Agency (SEA), Energy in Sweden 2009, SEA, Sweden, 2010, pp. 167.

[3] Swedish District Heating Association, Verksamhetsberättelse 2008/2009, Svensk Fjärrvärme, 2009, pp. 52. Web accessed at www.svenskfjarrvarme.se in August, 2010.

[4] Svensk Fjärrvärme, Statistik 2008 - tabeller och diagram, Svensk Fjärrvärme AB, 2010. Web accessed at www.svenskfjarrvarme.se in August, 2010.

[5] Swedish Energy Agency, Energy in Sweden 2008, SEA, Sweden, 2008.

[6] N. Stern, Stern review on the economics of climate change, 2006. Web access at www.hm-treasury.gov.uk in February, 2010.

[7] CEC (Chalmers EnergiCentrum), Biokombi Rya biomass gasification project, final report. (Biobränsleförgasning satt i system, slutrapport), report 2007:3, Chalmers University of Technology, Göteborg, Sweden, 2007.

[8] H. Hansson, S.E., Larsson, O. Nystroem, F. Olsson, B. Ridell, Electricity from new plants. Elforsk AB, Stockholm (SE), 2007.

[9] Swedish Wood Fuel Association and Swedish Energy Agency, Heating with wood powder, 2001. Web accessed at www.energimarknadsinspektionen.se on June 08, 2009.

[10] L. Gustavsson, District heating system and energy conservation - Part I. Energy, 9(1), 1994, pp. 81-91.

[11] J. Sjödin, and D. Henning, Calculating the marginal costs of a district heating utility. Applied Energy, 78(1), 2004, pp. 1-18.

[12] L. Gustavsson, and Å. Karlsson, $\mathrm{CO}_{2}$ mitigation: On methods and parameters for comparison of fossilfuel and biofuel systems. Mitigation and Adaptation Strategies for Global Change, 11, 2006, pp. 935-959.

[13]I. Obernberger, and G. Thek, Combustion and gasification of solid biomass for heat and power production in Europe - State-of-the-art and relevant future developments, Proceeding of the 8th European Conference on Industrial Furnaces and Boilers, Vilamoura, Portugal, 2008. 